\title{
May be Urinary Excretion of $\alpha 2$-macroglobulin (MW 720 kDa) a Proteinuric Marker of Podocytopathy? Insight from Analysis of 204 Patients with Glomerulonephritis (GN) and Nephrotic Syndrome, 177 with Functional Outcome.
}

\section{Running Title: Clinical significance of $\alpha 2 \mathrm{~m} / \mathrm{C}$ urinary excretion in GN \& NS.}

Claudio Bazzi *

D Amico Foundation for Renal Disease Research, Milan, Italy, Retired from Nephrology and Dialysis Unit, Azienda Ospedaliera Ospedale San Carlo Borromeo, Milan, Italy.

Corresponding Author: Claudio Bazzi, D Amico Foundation for Renal Disease Research, Milan, Italy.

Received Date: 19 August 2021 | Accepted Date: 01 September 2021 | Published Date: 04 September 2021

Citation: C Bazzi. (2021). May be Urinary Excretion of a2-macroglobulin (mw $720 \mathrm{kda}$ ) a Proteinuric Marker of Podocytopathy? Insight from Analysis of 204 Patients with Glomerulonephritis (gn) and Nephrotic Syndrome, 177 with Functional Outcome. International Journal of Clinical Case Reports and Reviews. 8(3); DOI:10.31579/2690-4861/165

Copyright: ( 2021 Claudio Bazzi, This is an open-access article distributed under the terms of the Creative Commons Attribution License, which permits unrestricted use, distribution, and reproduction in any medium, provided the original author and source are credited.

\begin{abstract}
Background: In IgAN with cellular crescents (CIgAN) urinary excretion of $\alpha 2$-macroglobulin $(\alpha 2 \mathrm{~m} / \mathrm{C}, \mathrm{MW} 720 \mathrm{kDa})$ may be a marker of podocytes damage induced by crescents. The purpose of the study was the evaluation of the clinical significance of $\alpha 2 \mathrm{~m} / \mathrm{C}$ excretion in 177 patients with glomerulonephritis (GN), nephrotic syndrome (NS) and functional outcome.
\end{abstract}

Methods: In all 177 patients $\alpha 2 \mathrm{~m} / \mathrm{C}$ excretion was measured; the patients were divided in 2 groups: $\alpha 2 \mathrm{mC}=0$ (n. 72 ) and $\alpha 2 \mathrm{~m} / \mathrm{C}>0$ (n. 105); for each group were assessed the outcomes considered in combination: Remission \& persistent nephrotic syndrome (PNS) with long lasting NRF designed "Remission \& NRF"; ESRD \& eGFR $<50 \%$ \& PNS with CRF designed "Progression and progression risk".

Results: In 72 patients with $\alpha 2 \mathrm{~m} / \mathrm{C}=0$ "Remission \& NRF" was $78 \%$ and "Progression \& progression risk" was $22 \%$; in 105 patients with $\alpha 2 \mathrm{~m} / \mathrm{C}>0$ "remission \& NRF" was $52 \%$ and "Progression \& progression risk" was $48 \%$. "Remission \& NRF" in each GN type with $\alpha 2 \mathrm{~m} / \mathrm{C}=0$ was: $100 \%$ in $\mathrm{MCD}$ and $\mathrm{LN} ; 82 \%, 79 \%, 67 \%$ in FSGS, IMN, MPGN; in $\alpha 2 \mathrm{~m} / \mathrm{C}>0$ "Progression and progression risk" was $0 \%, 38 \%, 46 \%, 54 \%, 56 \%, 85 \%$ in MCD, LN, IMN, MPGN, FSGS, CIgAN with cellular crescents, respectively.

Conclusion: urinary excretion of $\alpha 2 \mathrm{~m}$ is a very simple marker available in all clinical practice laboratories, marker of damage of podocytes at least in CIgAN and LN with crescents and marker of GFB damage in different GN types and useful to predict outcome and treatment responsiveness.

Keywords: Urinary Excretion; $\alpha 2$-macroglobulin; Proteinuric Marker; Podocytopathy; Glomerulonephritis; Nephrotic Syndrome

\section{Introduction}

In 2001 Bakoush et al. published the article "High proteinuria selectivity index based upon IgM (IgM-SI) is a strong predictor of poor renal survival in glomerular diseases" [1]. The study included 84 patients with glomerulonephritis (between them also IgAN and nephroangiosclerosis) without indication if all patients have nephrotic syndrome (NS). Among patients with high IgM-SI (n. 51) or low IgM-SI (n. 33) 11(22\%) with high IgM-SI and 0\% with low IgM-SI started dialysis after a follow up of 39 and 43 months, respectively. The Authors concluded that IgM-SI value is a strong predictor of clinical outcome in proteinuric glomerulopathies. In subsequent 20 years unfortunately no one study evaluated the clinical significance of urinary excretion of the other high MW proteins $\alpha 2 \mathrm{~m}$ (MW $720 \mathrm{kDa}$ ) whose excretion presuppose a severe alteration of glomerular filtration barrier (GFB). In a recent study [2] we assessed the urinary excretion $\alpha 2 \mathrm{~m} / \mathrm{C}$ in 58 patients with Crescentic IgAN 
(CIgAN) (37 with cellular and 21 with fibrous crescents) and in 125 patients with $\operatorname{IgAN}$ and persistent non-nephrotic proteinuria (PP). The comparison of urinary excretion of $\alpha 2 \mathrm{~m} / \mathrm{C}$ between the $58 \mathrm{CIgAN}$ patients and $125 \operatorname{IgAN}$ PP patients showed that $\alpha 2 \mathrm{~m} / \mathrm{C}$ excretion in CIgAN was 12.9 times higher than in $\operatorname{IgAN} P P(6.3$ vs $0.49, \mathrm{p}=0.0002)$ and 18.2 times higher in $37 \mathrm{CIgAN}$ patients with cellular crescents versus $125 \mathrm{IgAN}$ PP patients (8.94 versus $0.49, \mathrm{p}=0.0003$ ). The comparison between 37 patients with cellular crescents and 21 patients with fibrous crescents showed that $\alpha 2 \mathrm{~m} / \mathrm{C}$ was 7.07 times higher in patients with cellular crescents $(8.94$ vs $1.38, \mathrm{p}=0.001)$. In 21 patients with CIgAN and fibrous crescents compared with 125 patients with IgAN PP $\alpha 2 \mathrm{~m} / \mathrm{C}$ excretion was 2.82 times higher ( 1.38 vs $0.49, \mathrm{p}=0.22)$. The functional outcome was assessed in 34 of 37 patients with cellular crescents and evaluated according to quartiles of cellular crescents and $\alpha 2 \mathrm{~m} / \mathrm{C}$. The quartiles of cellular crescents showed a progressive increase of percentage of glomeruli with cellular crescents from $1^{\circ}$ to $4^{\circ}$ quartile (from 6.2 to $41.8 \%, \mathrm{p}=0.0006$ ); the quartiles of $\alpha 2 \mathrm{~m} / \mathrm{C}$ show a significant increase of $\alpha 2 \mathrm{~m} / \mathrm{C}$ from 2.9 to $12.2(\mathrm{P}=0.04)$. In $1^{\circ}$ quartile of $\alpha 2 \mathrm{~m} / \mathrm{C}$ remission with normal renal function was $67 \%$ and ESRD was $0 \%$, while in $4^{\circ}$ quartile Remission with NRF was $0 \%$ and ESRD 62.5\%. By contrast, the functional outcome of quartile of cellular crescents shows different predictive value: in $1^{\circ}$ quartile Remission with NRF $54 \%$ and ESRD $31 \%$; in $4^{\circ}$ quartile Remission with NRF $22 \%$ and ESRD $11 \%$. This difference may be dependent on that $\alpha 2 \mathrm{~m} / \mathrm{C}$ excretion assess the overall GFB damage, while the percentage of glomeruli with cellular crescents may be dependent on the various size of biopsy samples in different patients. On the basis of these data it was hypothesized that cellular crescents localized in the space between parietal epithelial cells of Bowman capsule and podocytes may damage the podocytes and slitdiaphragm $[3,4,5]$ allowing the passage of the high MW protein $\alpha 2 \mathrm{~m} / \mathrm{C}$. Thus it may be suggested that $\alpha 2 \mathrm{~m} / \mathrm{C}$ excretion could be a proteinuric marker of podocyte damage consequent to presence of cellular crescents. On the basis of these data the purpose of the study was the evaluation of the urinary excretion of $\alpha 2 \mathrm{~m} / \mathrm{C}$ in a large cohort of patients with GN (n. $177)$ to assess the clinical significance of $\alpha 2 \mathrm{~m}$ excretion: whether urinary excretion of $\alpha 2 \mathrm{~m}$ may be a marker of podocytopathy in $\mathrm{GN}$ with crescents and/or marker of GFB damage in GN patients without crescents.

\section{Patients and Methods}

The patients cohort included all patients attending the Nephrology and Dialysis Unit of San Carlo Borromeo Hospital, Milan, Italy, between January 1992 and April 2006 with renal biopsy diagnosis of GN with NS (n. 204); in 177 of them the functional outcome was available and these patients were the object of the study with the following types of chronic primary glomerulonephritis (GN) and Lupus Nephritis (LN) (Table 1): Focal Segmental Glomerulosclerosis (FSGS, n. 38) (6), Idiopathic Membranous Nephropathy (IMN, n.72) (7), Minimal change disease (MCD, n. 15), Membrano-proliferative glomerulonephritis (MPGN, n. 17: type I n. 11; type II n. 1; type III n. 3; fibrillary type n. 29) (8); Crescentic IgAN (CIgAN, n. 14)] and Lupus Nephritis [LN, n. 19: (LN classes: $3+5$ n. 2, 4 n. 15; 5 n. 2)]; IgA Nephropathy (IgAN n. 2). Inclusion criteria: nephrotic syndrome (proteinuria $\geq 3.5 \mathrm{~g} / 24 \mathrm{~h}$ ); at least six glomeruli in renal biopsy; typical features at light and immunofluorescence microscopy; no clinical signs of secondary GN except for LN. The functional outcome was available for all the 177 patients with rather long follow up: mean $86 \pm 72$ months (2-331). Five types of outcome were considered: 1) Remission of NS: complete: proteinuria $\leq 0.30 \mathrm{~g} / 24 \mathrm{~h}$; partial: proteinuria $\leq 2.0 \mathrm{~g} / 24 \mathrm{~h}$; 2) persistent NS with long lasting normal renal function (NRF) [follow up: 77 \pm 53 months (12-200)]; 3) progression to end-stage renal disease (ESRD) ; 4) eGFR reduction $\leq 50 \%$ of baseline; 5) persistent NS with chronic renal failure (CRF) and progressive eGFR reduction (from 49.3 to $39.1 \mathrm{ml} / \mathrm{min} / 1,72$ $\mathrm{m} 2$ ). Usually in prediction studies the outcomes considered are Remission and ESRD. We decided to evaluate not only each type of outcome considered independently but also the combination of outcomes with similar prognostic significance: Remission was evaluated in combination with persistent NS with long lasting NRF, afterwards indicated as "Remission \& persistent NRF"; ESRD and eGFR $\leq 50 \%$ were evaluated in combination with persistent NS with CRF characterized by eGFR progressive reduction and thus candidate for progression to ESRD, afterwards indicated as "Progression \& progression risk". The diagnosis and clinical presentation of patients are reported in Table 1.

\begin{tabular}{|c|c|}
\hline & $\begin{array}{c}\text { Nephrotic syndrome } \\
(\mathbf{n}=\mathbf{1 7 7})\end{array}$ \\
\hline Age, years & $41.2 \pm 17.5$ \\
\hline Men, $\mathrm{n}(\%)$ & $91(51 \%)$ \\
\hline Hypertension $(\mathrm{BP}>140 / 90), \mathrm{n}(\%)$ & $108(61 \%)$ \\
\hline eGFR ml/min/1.73m2 & $70.1 \pm 31.4$ \\
\hline Serum albumin, $\mathrm{mg} / \mathrm{dL}(\mathrm{n}=401)$ & $2.4 \pm(0.7)$ \\
\hline Serum IgG, $\mathrm{mg} / \mathrm{dL}(\mathrm{n}=401)$ & $668 \pm 528$ \\
\hline Urinary protein, g/24hour & $7.0 \pm 4.7$ \\
\hline Total urinary protein/Cre, $\mathrm{mg} / \mathrm{gCre}$ & $4688 \pm 3163$ \\
\hline Urinary $\alpha 2 \mathrm{~m} / \mathrm{Cre}$ & $10.21 \pm 17.31$ \\
\hline Urinary IgG/Cre & $252.8 \pm 297.0$ \\
\hline Urinary albumin/Cre & $3863 \pm 2497$ \\
\hline Urinary $\alpha 1 \mathrm{~m} / \mathrm{Cre}$ & $46.8 \pm 41.8$ \\
\hline Diagnosis, $\mathrm{n}(\%)$ & $14(8)$ \\
\hline CIgAN & $38(21)$ \\
\hline FSGS & $2(1)$ \\
\hline IgAN & $72(41)$ \\
\hline IMN & $19(11)$ \\
\hline LN & $15(8)$ \\
\hline MCD & $17(10)$ \\
\hline MPGN & \\
\hline
\end{tabular}

Table 1: Diagnosis and clinical, functional and proteinuric parameters in 177 patients with glomerulonephritis with nephrotic syndrome and functional outcome. 


\section{Laboratory Analysis}

Proteinuria was measured in 24 hour urine collection and second morning urine sample by the Coomassie blue method (modified with sodiumdodecyl-sulphate) and expressed as $24 /$ hour proteinuria and protein creatinine/ratio (mg urinary protein/g urinary creatinine). Serum and urinary creatinine were measured enzymatically and expressed in $\mathrm{mg} / \mathrm{dL}$. Serum albumin and $\operatorname{IgG}$ and urinary $\operatorname{IgG}, \alpha 2$-macroglobulin $(\alpha 2 \mathrm{~m})$, Albumin and $\alpha 1$-microglobulin $(\alpha 1 \mathrm{~m})$ were measured by immunonephelometry; urinary proteins were expressed as urinary protein/creatinine ratio $(\mathrm{IgG} / \mathrm{C}, \alpha 2 \mathrm{~m} / \mathrm{C}, \mathrm{Alb} / \mathrm{C}, \alpha 1 \mathrm{~m} / \mathrm{C})$. Estimated glomerular filtration rate (eGFR) was measured by the Chronic Kidney Disease Epidemiology Collaboration (CKD-EPI) formula (9) Three types of renal lesion that are markers of disease severity in any type of GN were evaluated: percentage of glomeruli with global glomerulosclerosis (GGS\%); extent of tubulo-interstitial damage (TID) evaluated semi-quantitatively by a score: tubular atrophy, interstitial fibrosis and inflammatory cell infiltration graded 0,1 or 2 if absent, focal or diffuse (TID global score: 0-6) and extent of Arteriolar Hyalinosis $(\mathrm{AH})$ evaluated semiquantitatively by a score: $0,1,2,3$ if absent, focal, diffuse, diffuse with lumen reduction, respectively (AH global score 0-4).

\section{Statistical Analysis}

Continuous variables are expressed as means \pm SD. Categorical variables are expressed as the number of patients (\%). The differences of mean were determined by t-test; categorical variables by the chi-square test. All statistical analyses were performed using Stata 15.1 (StataCorp LP, TX, USA). Two-sided $\mathrm{p}<0.05$ was considered statistically significant.

\section{Results}

In 177 patients with GN and NS and functional outcome [follow up 86 \pm 72 months (2-331)] the mean $\alpha 2 \mathrm{~m} / \mathrm{C}$ value was $10.2 \pm 17.2(0-113.2)$. The $\alpha 2 \mathrm{~m} / \mathrm{C}$ excretion increases from $0.74 \pm 1.57$ in $\mathrm{MCD}$ to $32.54 \pm 31.21$ in MPGN ( $x$ 43.9 times), while $\mathrm{IgG} / \mathrm{C}$ increases from $160 \pm 135$ to $422 \pm 472$ (x 2.63 times). The $\alpha 2 \mathrm{~m} / \mathrm{C}$ excretion increases progressively in different types of GN from MCD to FSGS, IMN, LN, CIgAN with cellular crescents and MPGN, respectively (Table 2). The high values of $\alpha 2 \mathrm{~m} / \mathrm{C}$ are significantly associated with reduction of eGFR and increase of GGS\%, TID score and AH score (Table 2). On the basis of these data showing very different $\alpha 2 \mathrm{~m} / \mathrm{C}$ excretion in the various types of GN to evaluate how $\alpha 2 \mathrm{~m} / \mathrm{C}$ excretion affects the functional outcome the patients were divided in two groups according to $\alpha 2 \mathrm{~m} / \mathrm{C}$ value: $\alpha 2 \mathrm{~m} / \mathrm{C}=$ 0 (n. 72) and $\alpha 2 \mathrm{~m} / \mathrm{C}>0$ (n. 105); this classification is useful also to assess in every type of GN whether the outcome is different in patients with $\alpha 2 \mathrm{~m} / \mathrm{C}=0$ and $\alpha 2 \mathrm{~m} / \mathrm{C}>0$. The overall outcome in the 177 patients was: Remission: 98 patients [55\%, follow up 107 \pm 79 months (12-331)]; PNS with long standing NRF: 13 patients [7\%, follow up 77 53 months (12200)]; ESRD: 39 patients [(22\%, follow up $41 \pm 32$ months (2-119)]; eGFR reduction $>50 \%$ of baseline: 10 patients [6\%; follow up $106 \pm 56$ months (18-191)]; PNS with CRF n. 17 [10\%; follow up $60 \pm 59$ months (18-248)]. We decided to evaluate not only each type of outcome considered independently but also the combination of outcomes with similar prognostic significance: thus Remission was evaluated in combination with persistent NS with long lasting NRF, afterwards indicated as "Remission \& persistent NRF"; ESRD and eGFR $\leq 50 \%$ were evaluated in combination with persistent NS with CRF characterized by progressive eGFR reduction and thus candidate to ESRD progression, afterwards indicated as "Progression \& progression risk". In patients with $\alpha 2 \mathrm{~m} / \mathrm{C}=0$ "Remission \& PNS NRF" is: $100 \%$ in MCD and $\mathrm{LN}, 82 \%$, $79 \%$, 67\% in FSGS, IMN, MPGN respectively (CIgAN with cellular crescents is not valuable as only one patient is $\alpha 2 \mathrm{~m} / \mathrm{C}=0$ ). In patients with $\alpha 2 \mathrm{~m} / \mathrm{C}>0$ the combined outcome "Progression \& progression risk" is $0 \%, 38 \%, 46 \%, 54 \%, 56 \%, 85 \%$ in MCD, LN, IMN, MPGN, FSGS, CIgAN with cellular crescents, respectively. This markedly different increase of $\alpha 2 \mathrm{~m} / \mathrm{C}$ in comparison to the other urinary proteins in the different types of GN and NS suggest that the excretion of $\alpha 2 \mathrm{~m} / \mathrm{C}$ may be dependent on a peculiar type of GFB damage that allows mainly the passage of the high MW protein $\alpha 2 \mathrm{~m}$, while the passage of other proteins even with high MW such IgG is markedly lower. In my recent study evaluating a $2 \mathrm{~m}$ excretion in patients with crescentic IgAN with cellular crescents the data were in support of the hypothesis that $\alpha 2 \mathrm{~m} / \mathrm{C}$ excretion could be a proteinuric marker of podocyte damage consequent to presence of cellular crescents. The observation that $\alpha 2 \mathrm{~m}$ excretion in patients with CIgAN with cellular crescents may be a marker of podocytes damage is also supported by the data of 19 patients with LN (n. 19): $11(58 \%)$ with crescents and $8(42 \%)$ without crescents with $\alpha 2 \mathrm{~m} / \mathrm{C}$ excretion 22.43 and 9.87 , respectively. Thus it may be suggested that $\alpha 2 \mathrm{~m} / \mathrm{C}$ excretion could be a proteinuric marker of podocyte damage in $\mathrm{GN}$ with cellular crescents. In patients without crescents $\alpha 2 \mathrm{~m}$ excretion may be a marker of different degree of GFB damage in every type of GN: absent in MCD, progressively increasing in FSGS, IMN, MPGN and very severe in LN and CIgAN with cellular crescent and in MPGN characterized in few patients $(12 \%)$ by crescents and by an immunofluorescent pattern of massive granular deposits of $\mathrm{C} 3$ and $\mathrm{IgG}$ along the capillary wall that may be associated with severe GFB damage. In conclusion the data of this study performed in a large cohort of patients homogeneous for selection (GN with NS) and with prolonged follow up, suggests that the very simple dosage of $\alpha 2 \mathrm{~m} / \mathrm{C}$ show a high outcome prediction ranging from $0 \%$ progression in $\mathrm{MCD}$ with $\alpha 2 \mathrm{~m} / \mathrm{C}=0$ to $85 \%$ of "Progression \& progression risk" in CIgAN with cellular crescents and $\alpha 2 \mathrm{~m} / \mathrm{C}>0$. Moreover this classification of patients shows the opportunity to evaluate the outcome according to treatment: no immune-suppressive treatment (n. 45) versus treatment with Steroids \& Cyclophosphamide (n. 103). In patients with $\alpha 2 \mathrm{~m} / \mathrm{C}=0$ remission is $63 \%$ in 45 untreated patients and $86 \%$ in 103 patients treated with steroids and cyclophosphamide; the difference between treated and untreated is lower in patients with $\alpha 2 \mathrm{~m} / \mathrm{C}$ $>0$ : remission $46 \%$ in untreated and $51 \%$ in patients treated with $\mathrm{St}+\mathrm{Cyc}$ suggesting that patients with $\alpha 2 \mathrm{~m} / \mathrm{C}>0$ the responsiveness to immunosuppression is lower eventually dependent on significantly higher data of TID score and AH score. 


\begin{tabular}{|c|c|c|c|c|c|c|c|c|c|c|}
\hline $\begin{array}{c}\text { Pts GN NS and functional. } \\
\text { outcome } \\
\text { n. } 177\end{array}$ & Age & $\begin{array}{l}\text { Basel. } \\
\text { eGFR }\end{array}$ & TUP/C & $\mathrm{IgG} / \mathrm{C}$ & $\alpha 2 \mathrm{~m} / \mathrm{C}$ & $\mathrm{Alb} / \mathrm{C}$ & $\alpha 1 \mathrm{~m} / \mathrm{C}$ & GGS\% & $\begin{array}{l}\text { TID } \\
\text { Score }\end{array}$ & $\begin{array}{l}\mathrm{AH} \\
\text { score }\end{array}$ \\
\hline $\begin{array}{l}\text { Patients with outcome } \& \\
\alpha 2 \mathrm{~m} / \mathrm{C}=0 \mathrm{n} .72\end{array}$ & $41.9 \pm 17.5$ & $83.7 \pm 29.8$ & $3612 \pm 2692$ & $123 \pm 138$ & $0 \pm 0$ & $3130 \pm 2368$ & $28.8 \pm 27.4$ & $8.5 \pm 12.7$ & $1.39 \pm 1.37$ & $0.36 \pm 0.67$ \\
\hline $\begin{array}{l}\text { Patients with outcome } \\
\& \alpha 2 \mathrm{~m} / \mathrm{C}>0 \text { n. } 105\end{array}$ & $40.7 \pm 17.5$ & $60.7 \pm 29.1$ & $5426 \pm 3260$ & $341 \pm 342$ & $17.3 \pm 19.5$ & $4367 \pm 2469$ & $59.3 \pm 45.5$ & $13.9 \pm 16.4$ & $2.30 \pm 1.82$ & $0.60 \pm 0.78$ \\
\hline $\mathrm{P}$ value & 0.66 & $<0.0001$ & $<0.0001$ & $<0.0001$ & $<0.0001$ & 0.0009 & $<0.0001$ & 0.05 & 0.003 & 0.06 \\
\hline $\begin{array}{c}\text { IgAN NS } \\
\text { n. } 2\end{array}$ & $50 \pm 11$ & $27.5 \pm 0.7$ & $2922 \pm 1429$ & $249 \pm 201$ & $0 \pm 0$ & $2295 \pm 1005$ & $91.5 \pm 1.4$ & $55.0 \pm 28$ & $5.00 \pm 0$ & $2.00 \pm 1.41$ \\
\hline $\begin{array}{l}\text { MCD NS } \\
\text { n. } 15\end{array}$ & $40 \pm 19$ & $92.1 \pm 30.2$ & $5349 \pm 2977$ & $160 \pm 135$ & $0.74 \pm 1.57$ & $4784 \pm 2180$ & $30.5 \pm 26.9$ & $5.6 \pm 7.3$ & $0.47 \pm 0.67$ & $0.13 \pm 0.39$ \\
\hline $\begin{array}{l}\text { FSGS NS } \\
\text { n. } 38\end{array}$ & $39 \pm 18$ & $80.3 \pm 30.4$ & $6170 \pm 4173$ & $198 \pm 157$ & $3.42 \pm 5.16$ & $5131 \pm 3373$ & $43.1 \pm 30.1$ & $6.8 \pm 9.9$ & $1.89 \pm 1.53$ & $0.37 \pm 0.64$ \\
\hline $\begin{array}{l}\text { IMN NS } \\
\text { n. } 72\end{array}$ & $47 \pm 18$ & $71.5 \pm 26.7$ & $4227 \pm 2466$ & $244 \pm 279$ & $8.15 \pm 12.75$ & $3514 \pm 1918$ & $47.2 \pm 44.3$ & $10.6 \pm 15.2$ & $1.32 \pm 1.28$ & $0.46 \pm 1.09$ \\
\hline $\begin{array}{c}\text { LN NS } \\
\text { n. } 19 \\
\end{array}$ & $35 \pm 17$ & $65.1 \pm 31.4$ & $3478 \pm 2996$ & $337 \pm 469$ & $15.96 \pm 22.14$ & $2684 \pm 2304$ & $38.7 \pm 38.9$ & $10.0 \pm 13.1$ & $2.52 \pm 1.48$ & $0.52 \pm 1.02$ \\
\hline $\begin{array}{l}\text { CIgAN NS cellular } \\
\text { crescents } \quad \text { n. } 14\end{array}$ & $28 \pm 8$ & $41.1 \pm 27.3$ & $3046 \pm 1367$ & $211 \pm 156$ & $17.47 \pm 14.83$ & $2452 \pm 1056$ & $48.2 \pm 35.3$ & $\begin{array}{c}25.5 \pm 16- \\
8 \\
\end{array}$ & $4.46 \pm 1.39$ & $0.93 \pm 0.78$ \\
\hline $\begin{array}{l}\text { MPGN NS } \\
\text { n. } 17\end{array}$ & $38 \pm 17$ & $55.9 \pm 33.4$ & $5657 \pm 3346$ & $422 \pm 472$ & $32.54 \pm 31.21$ & $4362 \pm 2395$ & $70.9 \pm 62.2$ & $17.4 \pm 15.9$ & $2.25 \pm 1.42$ & $0.94 \pm 1.32$ \\
\hline $\begin{array}{l}\% \text { increase }(\mathrm{x}) \text { of } \alpha 2 \mathrm{~m} / \mathrm{C} \\
\text { between MPGN NS vs } \\
\text { MCD NS patients }\end{array}$ & & & & × 2.63 & x 43.97 & & & & & \\
\hline
\end{tabular}

Table 2: Clinical, functional, proteinuric and histologic parameters in 177 patients with $G N$ and $N S$, and functional outcome, $n .72$ with $\alpha 2 \mathrm{~m} / \mathrm{C}=0$ and $n .105$ with $\alpha 2 \mathrm{~m} / \mathrm{C}>0$.

\begin{tabular}{|c|c|c|c|c|c|c|c|}
\hline & $\underset{n}{\text { Remissio }}$ & $\begin{array}{l}\text { PNS } \\
\text { NRF }\end{array}$ & ESRD & $\begin{array}{l}\text { PNS } \\
\text { CRF }\end{array}$ & $\begin{array}{c}\text { eGFR } \leq \\
50 \%\end{array}$ & $\begin{array}{c}\text { Remission \& } \\
\text { PNS NRF }\end{array}$ & $\begin{array}{c}\text { ESRD \& } \\
\text { PNSCRF \& } \\
\text { eGFR } \leq 50 \%\end{array}$ \\
\hline $\begin{array}{l}\text { All patients with } \alpha 2 \mathrm{~m} / \mathrm{C}=0 \mathrm{n} \text {. } \\
\qquad 72\end{array}$ & $52(72 \%)$ & $4(6 \%)$ & $7(10 \%)$ & $6(8 \%)$ & $3(4 \%)$ & $56(78 \%)$ & $16(22 \%)$ \\
\hline $\begin{array}{l}\text { All patients with } \alpha 2 \mathrm{~m} / \mathrm{C}>0 \\
\text { n. } 105\end{array}$ & $46(44 \%)$ & $9(9 \%)$ & $32(30 \%)$ & $11(10 \%)$ & $7(7 \%)$ & $55(52 \%)$ & $50(48 \%)$ \\
\hline $\mathrm{P}$ value & 0.00018 & & 0.001 & & & 0.0005 & 0.0005 \\
\hline $\begin{array}{c}\text { MCD NS } \alpha 2 \mathrm{~m} / \mathrm{C}=0 \mathrm{n} .11 \\
(73 \%)\end{array}$ & $\begin{array}{c}11 \\
(100 \%)\end{array}$ & $0(0 \%)$ & $0(0 \%)$ & $0(0 \%)$ & $0(0 \%)$ & $11(100 \%)$ & $0(0 \%)$ \\
\hline $\begin{array}{c}\text { MCD NS } \alpha 2 \mathrm{~m} / \mathrm{C}>0 \text { n. } 4 \\
(27 \%)\end{array}$ & $4(100 \%)$ & $0(0 \%)$ & $0(0 \%)$ & $0(0 \%)$ & $0(0 \%)$ & $4(100 \%)$ & $0(0 \%)$ \\
\hline $\begin{array}{c}\text { FSGS NS } \alpha 2 \mathrm{~m} / \mathrm{C}=0 \text { n.22 } \\
(58 \%)\end{array}$ & $17(77 \%)$ & $1(5 \%)$ & $1(5 \%)$ & $3(14 \%)$ & $0(0 \%)$ & $18(82 \%)$ & $4(18 \%)$ \\
\hline \multirow[t]{2}{*}{$\begin{array}{c}\text { FSGS NS } \alpha 2 \mathrm{~m} / \mathrm{C}>0 \text { n.16 } \\
(42 \%)\end{array}$} & $6(37.5 \%)$ & $1(6 \%)$ & $8(50 \%)$ & $1(6 \%)$ & $0(0 \%)$ & $7(44 \%)$ & $9(56 \%)$ \\
\hline & 0.01 & & 0.001 & & & 0.01 & 0.01 \\
\hline IMN NS $\alpha 2 \mathrm{~m} / \mathrm{C}=0 \quad$ n. 29 & $20(69 \%)$ & $3(10 \%)$ & $3(10 \%)$ & $2(7 \%)$ & $1(3 \%)$ & $23(79 \%)$ & $6(21 \%)$ \\
\hline \multirow[t]{2}{*}{ IMN NS $\alpha 2 \mathrm{~m} / \mathrm{C}>0$ n. 43} & $18(37 \%)$ & $5(12 \%)$ & $11(26 \%)$ & $5(12 \%)$ & $4(9 \%)$ & $23(54 \%)$ & $20(46 \%)$ \\
\hline & 0.02 & & 0.10 & & & 0.02 & 0.02 \\
\hline MPGN NS $\alpha 2 \mathrm{~m} / \mathrm{C}=0$ n. 3 & $2(67 \%)$ & $0(0 \%)$ & $1(33 \%)$ & $0(0 \%)$ & $0(0 \%)$ & $2(67 \%)$ & $1(33 \%)$ \\
\hline \multirow[t]{2}{*}{ MPGN NS $\alpha 2 \mathrm{~m} / \mathrm{C}>0$ n. 14} & $5(38 \%)$ & $1(7 \%)$ & $6(46 \%)$ & $0(0 \%)$ & $2(14 \%)$ & $6(46 \%)$ & $8(54 \%)$ \\
\hline & 0.32 & & 0.76 & & & 0.45 & 0.45 \\
\hline LN NS $\alpha 2 \mathrm{~m} / \mathrm{C}=0$ n. $\quad 6$ & $6(100 \%)$ & $0(0 \%)$ & $0(0 \%)$ & $0(0 \%)$ & $0(0 \%)$ & $6(100 \%)$ & $0(0 \%)$ \\
\hline LN NS $\alpha 2 \mathrm{~m} / \mathrm{C}>0$ n. 13 & $6(46 \%)$ & $2(15 \%)$ & $0(0 \%)$ & $3(23 \%)$ & $2(15 \%)$ & $8(62 \%)$ & $5(38 \%)$ \\
\hline CIgAN NS $\quad \alpha 2 \mathrm{~m} / \mathrm{C}=0 \quad$ n. 1 & 0.02 & & & & & 0.07 & 0.07 \\
\hline CIgAN NS $\alpha 2 \mathrm{~m} / \mathrm{C}>0$ n. 13 & $2(15 \%)$ & $0(0 \%)$ & $7(54 \%)$ & $3(23 \%)$ & $1(8 \%)$ & $2(15 \%)$ & $11(85 \%)$ \\
\hline
\end{tabular}




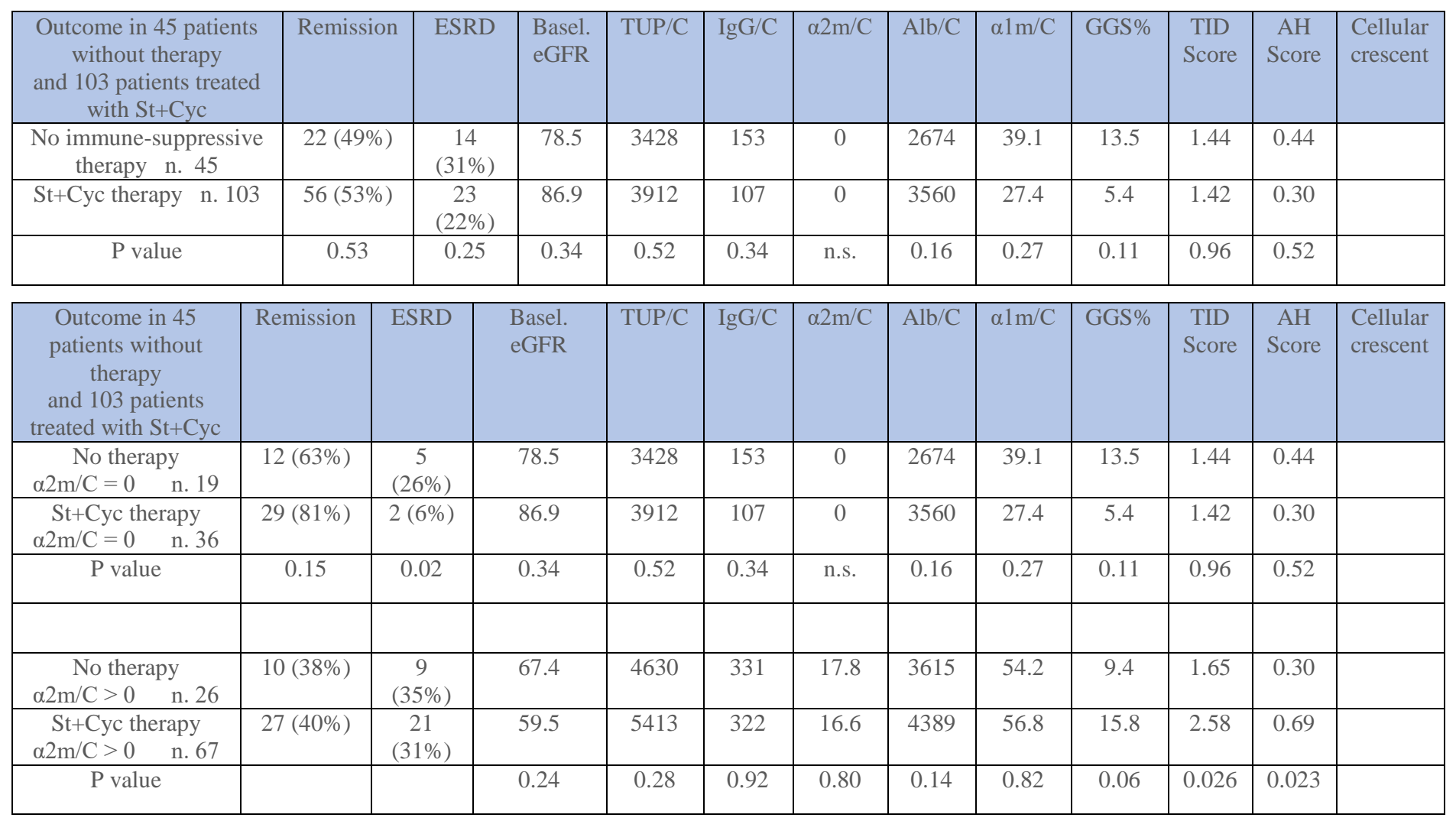

Table 4: Comparison of functional outcome (Remission and ESRD) in patients untreated with immunosuppression (n.45) or treated with Steroids and Cyclophosphamide (n. 103) according to $\alpha 2 \mathrm{~m} / \mathrm{C}=0$ or $\alpha 2 \mathrm{~m} / \mathrm{C}>0$

\section{Discussion}

The evidence of a significant higher $\alpha 2 \mathrm{~m} / \mathrm{C}$ excretion in Crescentic IgAN with NS and cellular crescents (CIgAN) in comparison to patients with IgAN PP and in Lupus Nephritis with crescents (10) in comparison with patients without crescents suggests that $\alpha 2 \mathrm{~m} / \mathrm{C}$ excretion may by a marker of podocytes damage induced by crescents (11). The observation that $\alpha 2 \mathrm{~m} / \mathrm{C}$ excretion progressively increases in other types of GN and NS without crescents such as MCD, FSGS, IMN, MPGN suggests that $\alpha 2 \mathrm{~m} / \mathrm{C}$ excretion may be a marker of progressive damage of GFB whose degree may affect the functional outcome. This role may be supported by the observation of increase of favourable functional outcomes in patients with $\alpha 2 \mathrm{~m} / \mathrm{C}=0$ in comparison with progressively unfavourable functional outcomes in patients with $\alpha 2 \mathrm{~m} / \mathrm{C}>0$; in patients with $\alpha 2 \mathrm{~m} / \mathrm{C}$ $=0$ the combined outcome "Remission and NRF" is $100 \%$ in MCD and $\mathrm{LN}$, and $82 \%, 79 \%, 67 \%$ in FSGS, IMN, MPGN respectively. In patients with $\alpha 2 \mathrm{~m} / \mathrm{C}>0$ the combined outcome "Progression and progression risk" is $0 \%, 38 \%, 46 \%, 54 \%, 56 \%, 85 \%$ in MCD, LN, IMN, MPGN, FSGS, CIgAN with cellular crescents, respectively. These data may suggest that in patients without crescents $\alpha 2 \mathrm{~m} / \mathrm{C}$ may be a marker of damage severity of GFB that according to value of $\alpha 2 \mathrm{~m} / \mathrm{C}(=0$ or $>0)$ may be the responsible of increased percentage of favourable or unfavourable functional outcomes.

\section{Conclusions}

On the basis of the data of a large cohort of patients with different types of GN and NS it is suggested that in all patients the level of $\alpha 2 \mathrm{~m} / \mathrm{C}$ is a very simple marker available in all clinical practice laboratories and useful to predict functional outcome and treatment responsiveness.

\section{Statement of Ethics and Disclosure Statement}

The study complies with the Declaration of Helsinki and local requirements for ethical approval. All patients gave their informed written consent. The article includes clinical research but no interventional studies. No financial support was received. The Authors have no ethical conflicts to disclose and no conflicts of interest to declare.

\section{Author Contribution:}

Research idea and study design: Claudio Bazzi

Data acquisition: Claudio Bazzi

Statistical analysis: Claudio Bazzi

\section{References}

1. Bakoush O, Torffvit O, Rippe B. and Tencer J. (2001) High proteinuria selectivity index base upon IgM is a strong predictor of poor renal survival in glomerular diseases. Nephrol Dial Transplant. 16(7):1357-1363.

2. Bazzi C. (2021) In Crescentic IgAN with Cellular Crescents the urinary excretion of the high MW Protein $\alpha 2$-macroglobulin may be considered e Proteinuric Marker of Podocytes Damage Induced by Cellular Crescents. Journal of Nephrology and Kidney Diseases. 4(1):128-135. 
3. Barièty J, Bruneval P, Meyrier A, Mandet C, Hill G, Jacquot C. (2005) Podocyte involvement in human immune crescentic glomerulonephritis. Kidney Int. 68(3):1109-1119.

4. Sekulic M, Pichler Sekulic S. (2013). A Compendium of Urinary Biomarkers Indicative of Glomerular Podocytopathy. Patholog Res Int.

5. Madhav C. Menon, 1 Peter Y. Chuang, 1 and Cijiang John He. (2012) The Glomerular Filtration Barrier: Components and Crosstalk. Int J Nephrol.

6. Bazzi C, Rizza V, Casellato D, Stivali G, Rachele G, Napodano P, Gallieni M, D'Amico G. (2013). Urinary IgG and $\alpha 2-$ Macroglobulin Are Powerful Predictors of Outcome and Responsiveness to Steroids and Cyclophosphamide in Idiopathic Focal Segmental Glomerulosclerosis with Nephrotic Syndrome. . Biomed Res Int.

7. Bazzi C, Rizza V, Casellato D, Tofik R, Berg A-L, Gallieni M, D'Amico G, Bakoush O. (2014). Fractional excretion of IgG in idiopathic membranous nephropathy with nephrotic syndrome: a predictive marker of risk and drug responsiveness. BMC Nephrol. 8; 15:74.

8. 8) Barbiano di Belgiojoso, Tarantino A, Colasanti G, Bazzi C, Guerra L, Durante A. (1977). The Prognostic Value of Some Clinical and Histological Parameters im Membranopro liferative Glomerulonephritis (MPGN): report of 112 cases. Nephron. 19(5): 250-258.

9. Levey AS, Stevens LA, Schmid LA, Zhang YL et al. (2009). CKD-EPI (Chronic Kidney Disease Epidemiology Collaboration) A new equation to estimate glomerular filtration rate. Ann Intern Med. 150(9):604-612.

10. Sakhi H, Moktefi A, Bouachi K, Audard V, Hènique C, Remy P, Ollero M, El Karoui K. (2019). Podocyte injury in Lupus Nephritis. J Clin Med. 8(9):1340.
This work is licensed under Creative Commons Attribution 4.0 License

To Submit Your Article Click Here: Submit Manuscript

DOI: $10.31579 / 2690-4861 / 165$
Ready to submit your research? Choose Auctores and benefit from:

$>$ fast, convenient online submission

$>$ rigorous peer review by experienced research in your field

$>$ rapid publication on acceptance

$>$ authors retain copyrights

$>$ unique DOI for all articles

$>$ immediate, unrestricted online access

At Auctores, research is always in progress.

Learn more www.auctoresonline.org/journals/international-journal-ofclinical-case-reports-and-reviews 